\title{
The Air Torpedo of Bäckebo Local Incident and World History
}

\author{
Mats Burström, Anders Gustafsson \& Håkan Karlsson
}

\begin{abstract}
In June 1944 a German V2-rocket exploded and crashed in Bäckebo in the province of Småland in southern Sweden. Technically the rocket represented the most modern the world had seen at the time. It laid the foundation for future space flights as well as for the fear of missiles of the Cold War. Today the incident in Bäckebo is largely forgotten or is unknown to people in Sweden. But what traces has the incident left locally? What kinds of memories still exist in the form of material remains and stories? Do parts of the rocket still remain in the ground? Can an archaeological survey for them trigger a process of remembering?
\end{abstract}

Mats Burström, Archaeology, Södertörn University College, SE-141 89 Huddinge, Sweden.

Anders Gustafsson, National Heritage Board, Box 5405, SE-114 84 Stockholm, Sweden.

Håkan Karlsson, Department of Archaeology, Göteborg University, Box 200, SE-405 30 Göteborg, Sweden.

Key words: contemporary past, V2-rocket, survey, materiality, memory, remembering process, re-use, reflexivity.

The $13^{\text {th }}$ of June 1944 was a beautiful Tuesday in early summer in the countryside at Bäckebo in the province of Småland, southern Sweden. Things were as usual. True, the world was at war, and a week earlier the Allied forces had landed in Normandy on D-Day. In neutral Sweden large numbers of men were away from home doing military service in other parts of the country, and most articles needed for everyday life were rationed. The war affected everyone, but still, the war had been going on for almost five years and people had become used to the situation and formed a new kind of normality.

On this day, schools were preparing to close for the summer. People were taking care of their daily business and enjoying the warm and sunny weather. At Gräsdal the farmer Robert Gustafson and his son Ivar were working out in the fields with their horses. It was just past three o'clock in the afternoon when the rural peace was broken - a huge explosion closely followed by a shock wave broke trees, blew out windows, and whirled up clouds of dust and leaves. It was as if the sky had broken into pieces. Robert Gustafson's horse, the old mare Daisy, fell down on her knees before running off in panic. Things were falling from heaven, making a rattling noise as they hit the trees and the ground. Small 


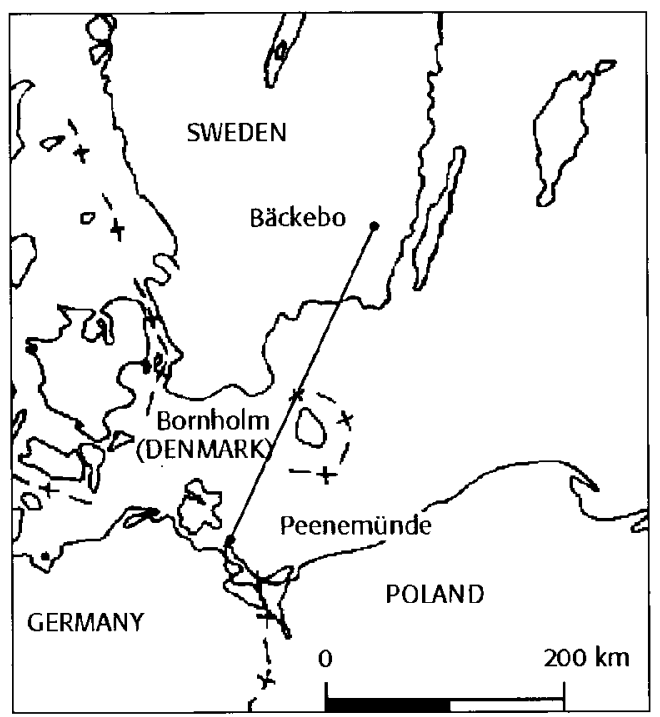

Fig. I. The southern Baltic.

fires started. The clear blue sky darkened, and those who looked up at the sky saw thousands of small, silvery, glittering objects floating down like falling leaves (Kjellson 1944; Heed 1963a).

What happened that day in Bäckebo was a local incident closely connected to world history. The incident was caused by something more modern than the world had previously seen a test rocket launched from the German research centre in Peenemünde on the Baltic coast. As a matter of fact,

it was so modern that there were no words to describe it. It was the first one of its kind to be exposed outside Germany or the German occupied territories (cf. Wahlström 1992:173) and for lack of better words the rocket was termed an air torpedo (Kjellson 1944). Technically this rocket laid the foundation for future space flights as well as for the fear of missiles of the Cold War.

Today, a little more than sixty years after the encounter with the most modern in Bäckebo, the incident has itself become history. But with the passage of time the incident has been overshadowed by countless other happenings and courses of events. As a result, the story of the air torpedo of Bäckebo is largely forgotten or is unknown to most people in Sweden. But what traces has the incident left locally? What kinds of memories still exist in the form of material remains and stories? Are there still parts of the rocket in the ground? Can an archaeological survey for them trigger a process of remembering? With these questions in mind we approached the Bäckebo Folklore Society (Sw. Bäckebo sockens hembygdsförening), and together with them and other locals we began to explore what memories the air torpedo has left.

\section{ARCHAEOLOGY OF THE CONTEMPORARY PAST}

As this study deals with a past that many people alive today have experienced themselves, it is positioned within the field of archaeology of the contemporary past. This field of research has a multidisciplinary character and collects inspiration, theories, and methods from academic disciplines such as anthropology, archaeology, ethnology, history, material culture studies, philosophy, and sociology (e.g., Appadurai 1986; Arvidsson et al. 1990; Miller 1998; Glassie 1999; Graves-Brown 2000; Buchli \& Lucas 2001). From this it follows that the field is heterogeneous and difficult to view as a whole, but also full of nuances and ideas. It also means that anyone who wants a clear-cut definition of archaeology 
of the contemporary past will be disappointed. Others will be stimulated by this open-mindedness.

Most people associate archaeology with the study of a distant past from which there exist few and fragmentary sources of information. It makes it easy to understand why archaeology is needed. But from the $20^{\text {th }}$ century there is an abundance of sources, which makes it reasonable to ask what archaeology possibly can contribute. The mere excess of information about the recent past is, however, in itself obscuring. The low-voiced history is at risk of drowning in the noise of other more dominant and loud-voiced sources. An important archaeological contribution is therefore to give voice to some of those histories that otherwise are not heard (cf. Buchli \& Lucas 2001:14-15). These low-voiced histories can give a human perspective on large-scale happenings and courses of events that we otherwise only hear about on a general level.

A central aspect of archaeology of the contemporary past is that it brings histories to the fore. This means that an excavation is not just a search for new information; it is also a happening that attracts people's attention and puts the recent past of that particular site in focus. The most important information is not always that which is found in the ground; it can very well be that which is told by local people or found in archives. But the archaeological effort is nonetheless what brings that history to the fore and triggers a remembering process. The archaeological work makes people talk and thus generates oral information that otherwise never would have been given.

Most people find it easier to relate to the contemporary past, of which they have more knowledge than the distant past. People enjoy recognising things they remember from their own past or have been told about by older relatives or friends. Many are surprised by the archaeological interest in such recent periods of time; the realisation that a past they have experienced themselves has now become subject to archaeology is cause for reflection about that past as well as the passage of time. It may also very well be a starting point for an interest in the more distant past.

Working with time periods from which people have memories of their own calls for ethical considerations. People who are personally concerned by the research have the right to have their voice heard as well as to protect their own memories. There may also be those who do not want anyone to dig in "their" past. Their right to forgetfulness must be balanced against others' right to remembrance.

The most well known example of archaeology of the contemporary past is the Garbage Project that has been going on in the US since 1973 (e.g., Rathje \& Murphy 2001). The project has demonstrated a considerable difference between the consumption people say they have and the factual consumption their rubbish bears witness to. The reason for this does not have to be that people deliberately give false information to make a better impression; it can also be that the experienced and factual reality differs in a most interesting way. And what reality is in 
that case the real one? Regardless of which, this is a good example of how different kinds of sources give different information and how this leads to new questions and a more profound understanding.

Many excavations of the contemporary past have been within the field of forensic archaeology (cf. e.g., Cox 2001; Doretti \& Fondebrider 2001). Mass graves and other remains from violence and war crimes have been analysed to elucidate what happened and to identify the dead. These excavations have a clear therapeutic function; for many of the relatives of the victims, knowing what happened to their loved ones makes it easier to find some kind of peace and to carry on with their lives. For society to dig in the ground and prevent the past from lying untouched is a way to demonstrate that the victims are not forgotten nor the crimes they fell victim to.

In the last couple of years much interest has been focused on military remains from the Cold War. The reason is the large number of constructions and sites which are now being abandoned by the military and which therefore have become an issue for the cultural heritage management (e.g., Schmidt \& von Preuschen 2005; Schofield 2005). While this focus risks creating a reputation for archaeology of the contemporary past as being too military oriented, it is important to recognise the enormous proportions these installations had during the Cold War. For those of us who grew up in peaceful and officially neutral Sweden during this period, its material testimony seems like yet another example of the difference between experienced and factual reality.

\section{HISTORICAL BACKGROUND}

The rocket that crashed in Bäckebo was a test rocket of model A4 better known as V2 (Germ. Vergeltungswaffe 2, Eng. Retaliation weapon 2) - which had been launched from the German research centre at Peenemünde (cf. Bode \& Kaiser 2002). After a few minutes and a 350-kilometre-long flight the rocket exploded at high altitude near Bäckebo (Kjellson 1944; King \& Kutta 1998:225). It was probably the fuel chamber that exploded since airbursts due to this were a common malfunction of the V2 (Neufeld 1995:220-24).

Fig. 2. A model of a V2-rocket raised around a flagpole outside Kulturmacken in Bäckebo. Photo: Håkan Karlsson.

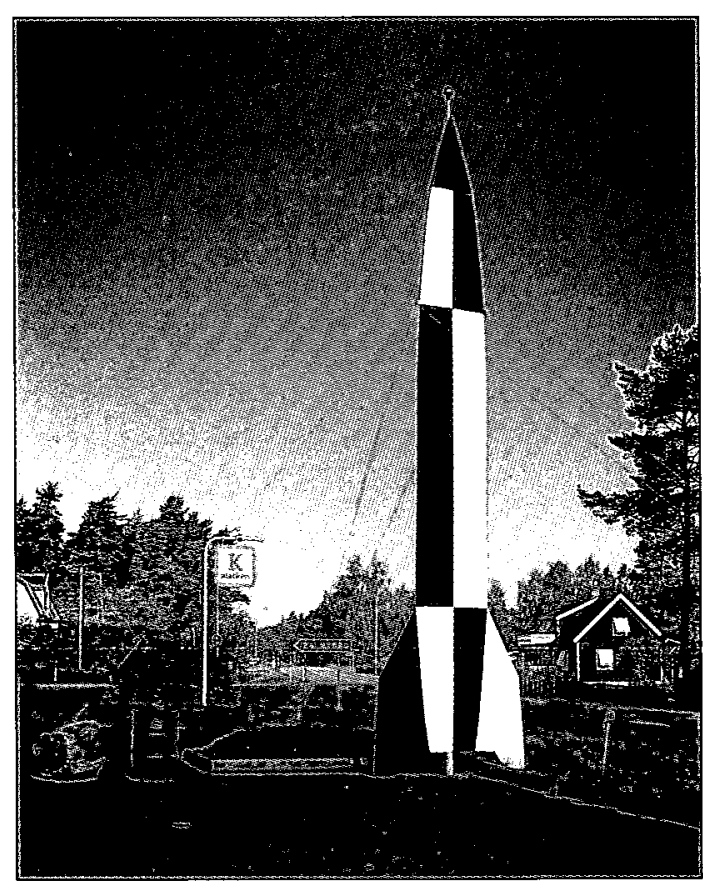


The V2-rockets were 14 metres long and weighed 13 tons, including 9 tons of liquid fuel. Every rocket could carry 1-3 tons of explosives and had a top speed of about $5700 \mathrm{~km} / \mathrm{h}$ (Longmate 1985; Dornberger 1989). When the rocket crashed in Bäckebo the V2's were still in an experimental stage. They were put into military action in September 1944, and until March 1945 a total of approximately 3000 V2-rockets were fired toward targets in Belgium, France and Great Britain (Iko 2004). In England nearly 3000 civilians were killed by V2-rockets, the attacks against London being the most devastating (Wahlström 1992:174; Neufeld 1995; Dungan 2005).

From a military point of view the V2-rocket was an expensive and inefficient weapon. Its greatest importance was on a psychological level as it spread horror among the civilian population in the cities under attack. As the V2-rockets reached their targets at supersonic speed, there were no forewarnings nor could they be shut down (Neufeld 1995).

The V2-rocket was a result of the German rocket research programme, which since 1936 was located in Peenemünde and led by Wernher von Braun (Bode \& Kaiser 2002:50; cf. Burström 2004a). This research was world leading, and in October 1942 a V2-rocket launched from the famous Prüfstand VII was the first rocket ever to reach into space (cf. Dornberger 1989; Neufeld 1995:164-65; Bode \& Kaiser 2002:50). After the war German rocket engineers and their research results were taken to the US and to the Soviet Union. At these new locations research continued and intensified as a part of the arms race and the space programmes. Von Braun became head at NASA for developing the rocket that in 1969 put a man on the moon (cf. Bergaust 1976; Simpson 1988; Gimbel 1990).

\section{THE CRASH}

The V2-rocket that exploded over Bäckebo was a test rocket (no. 4089) equipped with a special electronic device for controlling the rocket from the ground via telecommunication (Kjellson 1944; Neufeld 1995:234-235). The fact that the rocket exploded over Swedish territory instead of crashing into the sea outside Bornholm where there were German observation points was most probably a mistake due to technical malfunction.

Over the years there have, however, been many speculations that the crash in Bäckebo was intentional. Some people think it was intended as a warning to Sweden, others have speculated that it was a way for the Germans to test the maximum flight distance. They refer to a mysterious motor hearse with a white coffin in the back that was seen in Bäckebo right after the crash (cf. Heed 1963b; Håkansson 1987). They believe that it was German agents checking the crash site, for how could they have been there so fast if they did not know beforehand what was going to happen? To be driving around on local bypaths in a motor hearse seems, of course, to be a rather unsuccessful attempt to avoid attention. But nonetheless it has been suggested that the coffin was intended for collecting vital parts of the rocket (Heed 1963b, 1968a). We have also heard speculations 


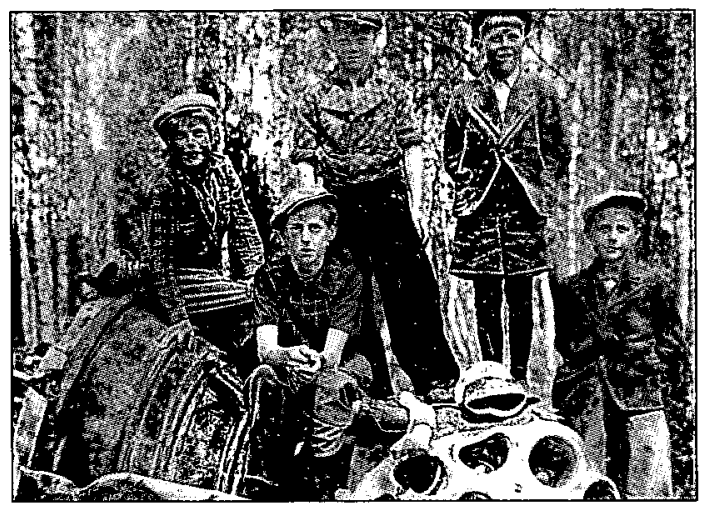

Fig. 3. Boys posing on the rocket motor. Photo: Verner Andersson.

that the rocket was intended to hit the railway stationhouse in nearby Knivingaryd. The reason for choosing this target is not entirely clear, but it was probably meant as a precision test.

A couple of hours after the crash the Swedish Home Guard arrived at the site and sealed it off. But before any guarding was organised, curious people from the surrounding farms and villages had gathered and started to collect souvenirs and things they considered useful. Fragments of the rocket were found in a four-square-kilometre large fall-out area; large tangles of cables were hanging down from the trees, and on the ground there were fragments of aluminium sheets, wrecked metal parts and different kinds of mechanical and electronic equipment. The largest object was a huge, hourglass-shaped feature that was about 1.7 metres long, 1 metre in diameter, and about $450 \mathrm{~kg}$ in weight. It was later found to be the combustion chamber of the rocket motor (Kjellson 1944).

At the crash site there was a large crater in the ground, approximately 5 metres in diameter and 2.5 metres deep. Around it trees were cracked, and there were fragments of iron sheets on the ground. The crater was probably created when the warhead charge, which was supposed to destroy the equipment if the rocket went astray, hit the ground and exploded (Kjellson 1944).

When experts from the air wing in Kalmar (F 12) arrived at the site they soon realised that the wreckage did not belong to an ordinary aeroplane. The fall-out area was carefully searched and the military conducted search parties with men crawling on their hands and knees. One of them remembers that the mosquitoes and the rough terrain made the search a real plague (cf. Burström et al. 2005b). The military also used metal detecting devices (Heed 1963b).

The authorities soon realised that a lot of objects including vital parts had been taken from the crash site (Kjellson 1944). Through appeals in local newspapers and notices, and via schoolteachers, people were urged to hand in what they had taken. They were instructed to put the rocket parts on their front steps to be collected by the police. According to the police, rockets parts were collected from the steps of about 80 houses (Heed 1963b, 1968b).

Slightly more than two tons of material remains from the rocket were gathered and taken on trucks to the air wing in Kalmar. There they were locked into a hangar until further transport to Bromma airport in Stockholm and the Defence Aeronautical Experimental Institute (Sw. Flygtekniska försöksanstalten) (Kjellson 1944). 


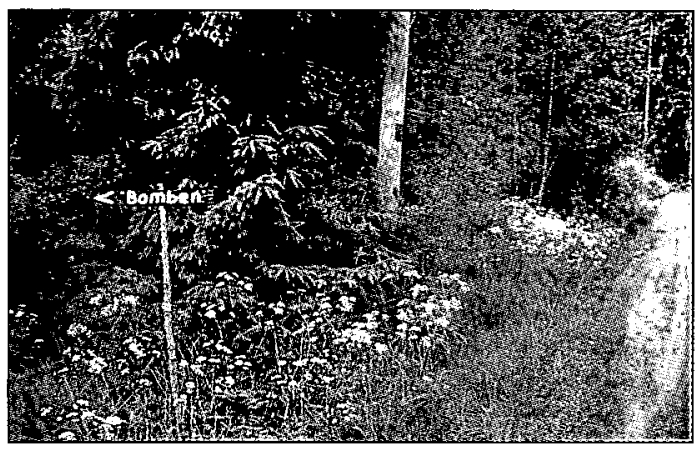

Fig. 4. Pointing the way to the impact crater: Photo: Mats Burström.

In Stockholm the material remains were analysed by various experts, and they made impressively correct conclusions about the rocket's construction and performance. The Allies were eager to get information on this new weapon, and after strong demands the rocket parts were transported with an American aircraft to Scotland, and then further on to London for analyses (Heed 1963d, 1968b; SVT 1979; Johansson 1985, 1994; Lundgren 1989; Wahlström 1994; King \& Kutta 1998:226).

\section{LOCAL CONTEXT}

Today the rocket's impact crater is still visible in the woods northeast of the small farm of Gräsdal. During the years it has caved in a little but it still constitutes a well-visible reminder of what once happened there. Down at the local bypath there is a homemade sign pointing the way to the crater. The text simply states Bomben, that is, "The Bomb". At the crater there is also a sign with brief information about the incident in June 1944. It was made by the Swedish Air Force Museum and put there by the Bäckebo Folklore Society in connection with the $50^{\text {th }}$ year anniversary.

By happy chance our interest in what traces the air torpedo has left locally coincided with the approaching $60^{\text {th }}$ year anniversary of the crash. In Bäckebo there is an old and shut down petrol station that some locals have transformed into a "cultural station" named Kulturmacken. We made contact with one of the driving forces, Lena Arén, who told us that in the summer of 2004 the anniversary would be commemorated with a small exhibition in the former garage. When the event finally took place on the $13^{\text {th }}$ of June, sixty years to the day of the crash, Håkan Juholt, who then was chairman of the Defence Committee (Sw. Försvarsutskottet) of the Swedish Parliament, opened the exhibition where among other things some privately possessed rocket parts were displayed. We were present and met with persons who had memories of the crash. We invited them and all others interested to work together with us in exploring the traces the air torpedo has left locally.

Fig. 5. Hakan Juholt opens the exhibition at Kulturmacken in Bäckebo. Photo: Mats Burström.

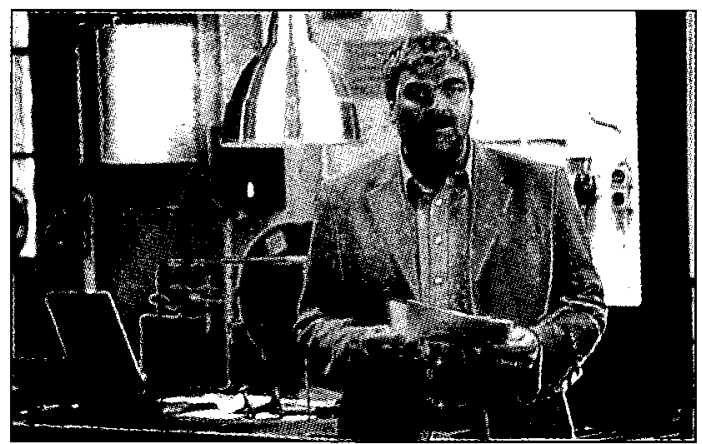




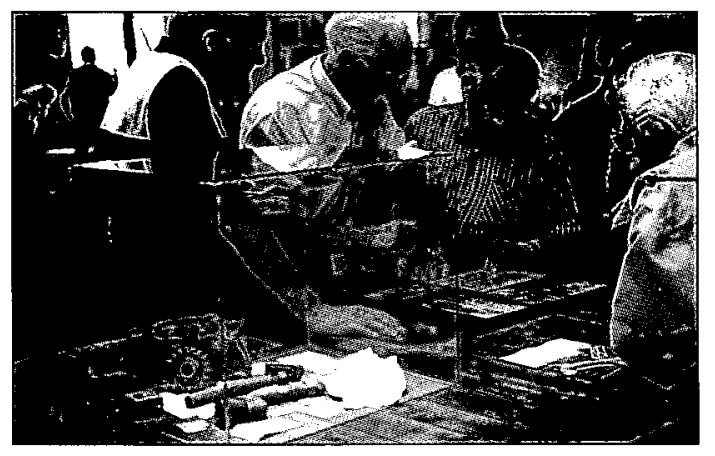

Fig. 6. Parts of the air torpedo exhibited in Kulturmacken. Photo: Mats Burström.

Prior to the exhibition, we had approached the Bäckebo Folklore Society. They were positive to our plans and invited us to the so-called Bäckebo Day later that summer. This is a day when people living in Bäckebo get together and socialise with people who used to live there and who now return for a day. On this occasion, the $29^{\text {th }}$ of August 2004, we presented our general ideas, asked for views and information, and invited everyone to take part in the project. As a result we got a list of about twenty names.

\section{ARCHAEOLOGICAL FIELDWORK I:}

\section{METAL DETECTOR SURVEY}

In 1944 the authorities managed to collect $2010 \mathrm{~kg}$ of material remains from the rocket at the crash site and from people who had taken parts (Kjellson 1944). The rocket is, however, calculated to have weighed approximately three tons without fuel and explosives. This means that about one ton is still missing (Erlandsson 1995). Some of the missing parts probably fell down in fields of corn, marshes and small pools of water that were not searched by the military at the time (Kjellson 1944). We also know that some of the rockets parts taken by private persons were not handed over to the authorities despite appeals to do so. Other parts can have been found many years after the crash when nobody was interested in collecting them (cf. Heed 1963a-b; Håkansson 1987).

There can also still be rocket parts lying in the ground. In discussions of this with locals, there were different opinions. Some believed that the military back in 1944 had done such a thorough search that there would not be anything left to find, especially considering the amount of time that had passed since then. Others believed that it would have been impossible for the military to find everything regardless of how carefully

Fig 7. Lena Arén and Kajsa Lembke investigating a metal detector response. Photo: Håkan Karlsson.

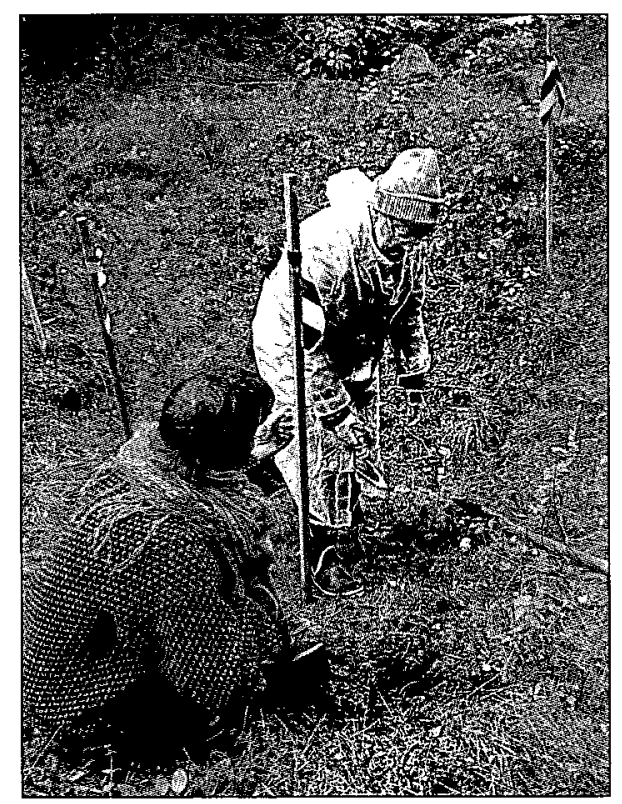




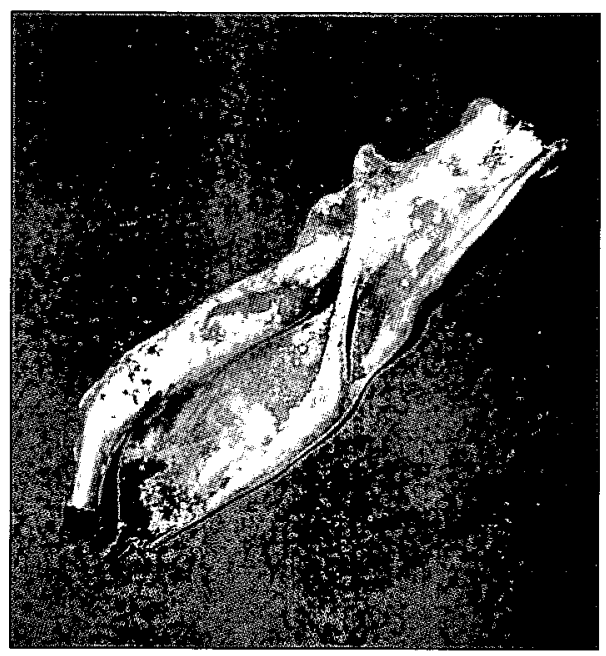

Fig 8. Remains of an aluminium tube found at the metal detector survey. Photo: Håkan Karlsson.

they searched. And, if so, with the right equipment it should still be possible to find parts of the air torpedo.

The question whether or not there were still parts of the rocket to be found in the ground seemed to be a good starting point for archaeological fieldwork. The question is interesting in itself as it puts the 1944 search party in perspective. And more important, to conduct such a survey together with locals is a way to start and develop a dialogue. Working together and solving the different kinds of practical problems that always arise during fieldwork is an effective way to get to know each other. To dig in the ground is not just a way to possibly find artefacts, but also a way to meet and to start talks and discussions that otherwise would not have taken place. So we decided to survey the impact crater and the adjacent area with metal detectors.

After receiving the necessary permission from the County Administrative Board (Sw. Länsstyrelsen) in Kalmar and the landowners, we conducted a metal detector survey together with locals during the clear and sunny days of $1^{\text {st }}-3^{\text {rd }}$ October 2004. The fieldwork was a positive experience; we had a very nice time and shared many thoughts and stories about the incident in 1944 and what happened in its wake. We had people visiting the ongoing fieldwork and they told us about other persons we ought to speak to. The survey also attracted interest from the media and there were articles published in the local newspapers Barometern (Arenius, Emma 2004) and Östran (Arenius, Eric 2004) as well as a report on the regional television news (TV4).

The metal detector survey yielded good material results (Burström et al. 2005c). We found a total of 37 objects of metal. Of these, we interpret all but one to be parts of the rocket. Of the 36 rocket parts, 24 are of iron, 11 of aluminium, and 1 consists of both materials. The objects are of varying sizes, from fragments of aluminium with a weight of less than 1 gram to an iron part that

Fig. 9. Bertil Lembke interviewed by Emma Arenius from Barometern, a daily paper. Photo: Håkan Karlsson.

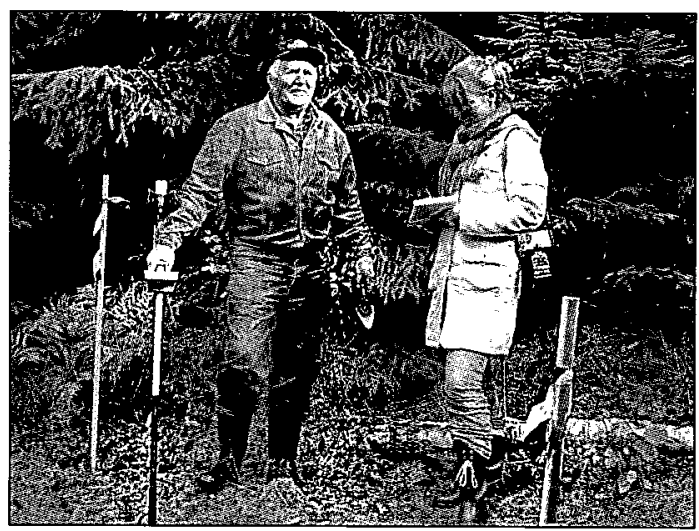


weighs $1.9 \mathrm{~kg}$. A number of the objects are possible to identify as specific parts of the rocket construction, for example tubes of aluminium that have been pressed flat. The metal detectors also gave response to a kind of light, metal powder that probably is the remains of disintegrated fragments of aluminium. When the analyses are finished the rocket parts will be repatriated to the collections of the Folklore Society in Bäckebo.

\section{ARCHAEOLOGICAL FIELDWORK II: MEMORY SURVEY}

A little more than a year after the metal detector survey we were back in Bäckebo to talk with people who possess rocket parts or have other kinds of memories or stories to tell. These were persons we had met during our earlier visits or whom we had been told about and then come in contact with. During $21^{\text {st }}-23^{\text {rd }}$ of October 2005 we, together with Lena Arén from Kulturmacken, met and talked with about 15 persons.

As archaeologists our main interest in this second part of fieldwork was to study how material remains of the rocket have been kept or re-used and what kind of stories they are associated with. We were especially interested in how rocket parts can trigger memories; how they may make people remember things that they otherwise would not have thought about (cf. Hoskins 1998; Forty \& Küchler 1999; Burström 2001, 2004b, 2005; Hallam \& Hockey 2001). Our intention was not to make a complete survey of all privately possessed parts of the air torpedo or memories associated with them. What we wanted to do was to explore the relations between materiality and memory.

Many of the memories and stories we have been told relate to individual experiences or specific rocket parts. In spite of this they are often of a kind shared by many others, which makes it possible to present them arranged in a number of themes.

\section{The secret}

Even today there is a lot of hush-hush about the rocket parts that were taken by private persons directly after the crash and not given to the authorities. Several persons presumed to possess rocket parts have told us directly, or via others, that they do not want to discuss the matter. Others have told us that they know people who have parts, but they will not say who they are. It is as if they do not want to betray them and reveal their secret. One reason for this attitude can, of course, be that they are afraid that we are going to take the rocket parts away from them and give them to a museum or some other authority. We have made assurances to the contrary, but all the same some persons may be sceptical of our intentions.

Fig. 10. Proud finders and possessors of parts from the Bäckebo air torpedo. Upper left: Bengt Erlandsson, Knivingaryd. Upper right: Harry Johansson, Alsterbro. He has donated his part to the Bäckebo Folklore Society. Lower left: John Erik Eriksson, Gräsdal. Lower right: Bengt Johansson, Alsterbro, showing a part from the collections of the Bäckebo Folklore Society. Photo: Mats Burström. 


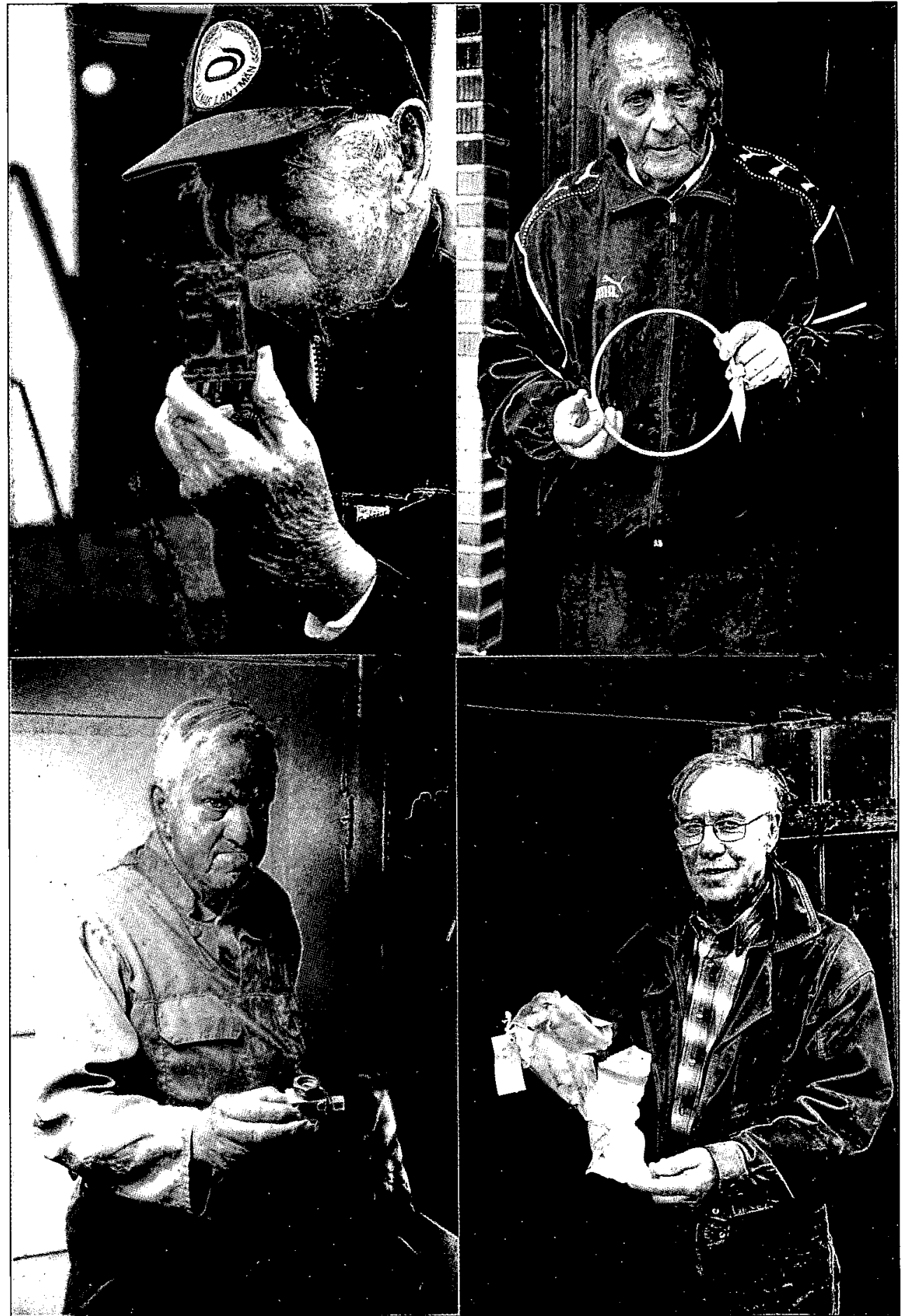


Another reason for not wanting to show or talk about privately possessed rockets parts is that everyone knows that they were supposed to turn them over to the authorities in 1944. For some reason or other they did not, and some people may be a little embarrassed about that. On the other hand, they may also feel proud of their venture. On a small scale, not giving up rocket parts might have been a way for them to show that they were their own masters and not easily commanded by the authorities.

Several of the persons we talked with remember very well the precise moment when they took their rocket part. As they knew it was forbidden, it was also exciting. One person, 25 years old at the time, says that he very quickly pulled his piece off a larger part of the rocket and immediately hid it in his pocket. $\mathrm{He}$ told no one about it, except his brothers, and he never bragged about it. At the time he hid his piece in the loft of an outhouse, but later he has kept it in an arms locker. Another person, 31 years old in 1944, hid the part he found under his sweater. He told no one about it, and he and his wife have kept the part on a shelf above a closet for many years.

One man remembers that, as a child, he was sitting behind his house when the local police arrived and his father suddenly shouted: "Here comes Inspector Östergren, now you have to hand over your parts!" But he took a small piece of a radio-unit and hid it in his pocket. Today the rocket piece reminds him of this situation and his father.

\section{The vital part and the re-use}

A notion held by several persons who possess parts of the rocket is that their specific part probably is a central and vital component of the rocket and its function. Thus, these parts are described as the "brain" or the "heart". One person, a 12-year-old boy in 1944, has appeared in newspaper articles and confessed: "I took the brain of the monster" (Heed 1963c, 1968b). There is also a later photo of him showing a chain from the rocket's steering system that he still possesses. In one article he says that he is considering having it framed (Johansson 1985).

One person, 25 years old in 1944, told us that he pulled his part from a large tangle of cables and that it shone like silver and gold. He is convinced that his part must have been the heart of the rocket: "It was from there everything was steered." Another person, who has inherited a part of the rocket from his uncle, also describes his part as the heart.

The air torpedo was in the absolute forefront of the technology of its time, and many of the parts collected by private persons were naturally of a kind they had never seen before. It was consequently very difficult to understand their precise function, and this made it easier to draw the conclusion that these were very advanced and vital parts. What they had found was a trophy representing not only the specific rocket that crashed in Bäckebo but also the most modern technology in the world, and as such it has been valued and kept ever since. In at least one case it has, as mentioned, been kept in an arms locker for safety reasons. 


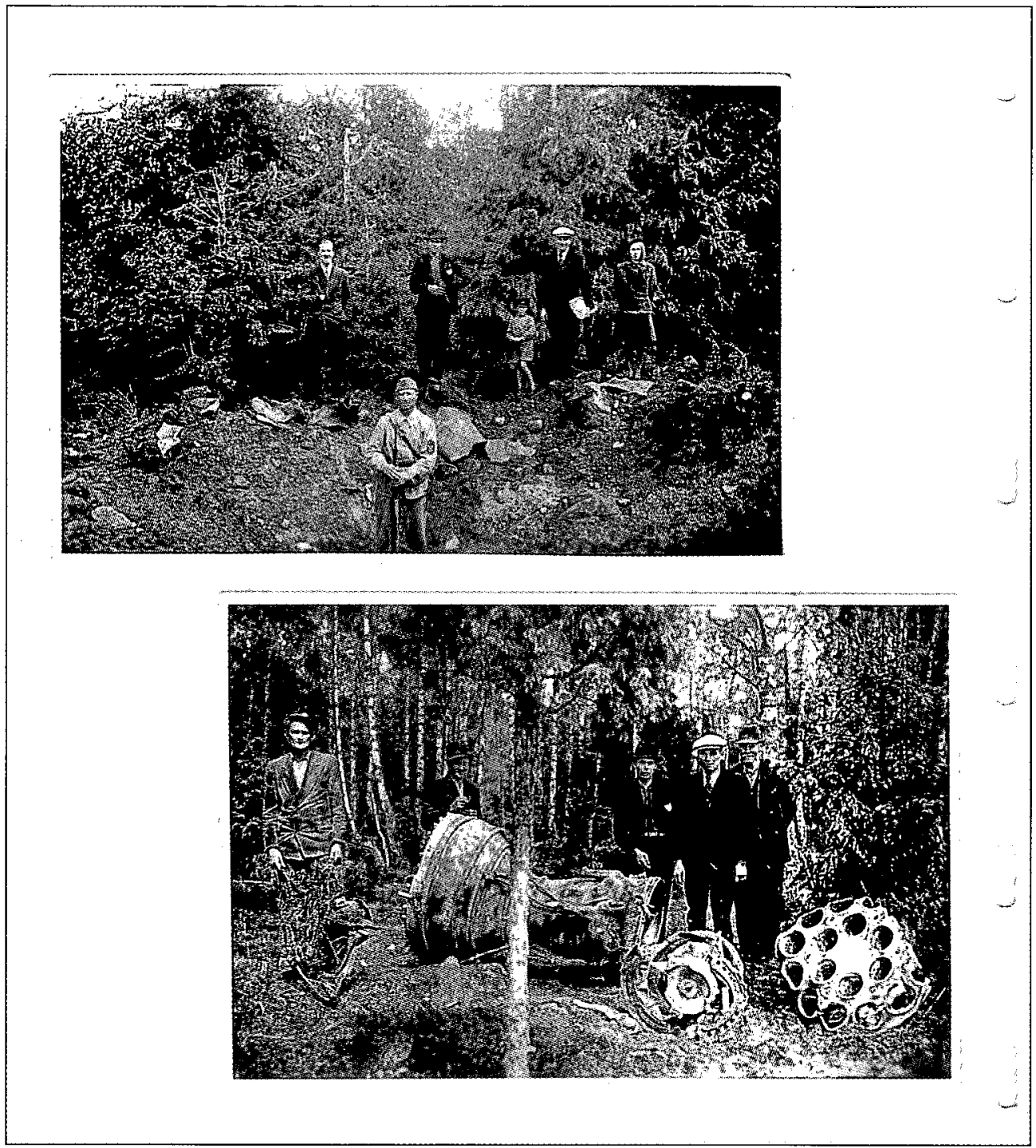

Fig. 11. Photos of the impact crater and the rocket motor mounted in a family album. Photo: Erik Johansson.

For those who do not know their origin, most rocket parts look like any other kind of metal rubbish. As a matter of fact, we ourselves were first quite sceptical of an object presented as part of the rocket. We thought it resembled a pipe from an old bathroom. We know now - we think - that we were wrong, but it illustrates that many rocket parts look like and can have been thrown away as rubbish.

Parts from the rocket have also been put to more practical use. One farmer, 31 years old in 1944, repaired the seat on his horse-driven rake with a piece of sheet metal from the rocket. He called it the "Hitler-sheet" (Sw. Hitlerplàten). Of another piece of aluminium he made a shovel with a wooden handle. This was then used 
to shovel food to the chickens and the pig. This practical use of the material that had fallen from the sky is characteristic of an attitude among many small farmers at the time. They worked hard to be as self-supporting as possible; this meant that nothing should be wasted and that most everything was put to use or re-use.

There are other examples of re-use of rocket parts; aluminium sheets are said to have been used to make a snuffbox (Heed 1963c, 1968b) and a cigarette case, and copper wire to make snares to catch pike (cf. Vilnersson 1998:32) and for arranging bee hives.

Instead of actual parts of the rocket some people have kept photos as memories of the incident. In 1944 a local photographer, Erik "Bio-Erik" Johansson, took pictures of the crashed rocket and the impact crater before the military sealed off the area. These pictures were then sold locally. In some cases they share space, as memories, with family pictures in photo albums.

\section{The scared horses}

The rocket crash in Bäckebo was a completely unexpected happening, impossible to foresee, and the explosion and the blast wave was a shocking and literally shaking experience. People fell to the ground, and one person told us that he almost blew off a horse wagon. The guesses as to what had happened were many. Some thought it was an aeroplane that had crashed. A father told his son that it was probably the Germans and now the war was here. An old woman was told that the Russians had bombed Nybro, a small town close by.

Although these suggestions indeed are dramatic, few of the persons we talked with spontaneously remember that they or others were scared. There are exceptions; one man still remembers the look on his mother's face and how he as a child understood how frightened she was. His father was doing military service in another part of Sweden and his mother was home alone with the children. What would happen now? Was it war?

Most people, however, do not refer to how they or other people felt but to how the horses reacted to the explosion and the blast wave. There are several stories about horses falling or sinking to the ground and then running off in panic. The story most often told is the one about the small farmer Robert Gustafson and his son Ivar who were working out in the fields with their horses at Gräsdal. At the explosion the horses fell down on their knees and then ran away in panic. This is the story we ourselves began this paper with. It was presented in writing already in the first secret military analyses of the air torpedo (Kjellson 1944) and it has been told and re-told in text ever since (e.g., Heed 1963a, 1968a; Lundgren 1989; Erlandsson 1995; Jeppsson 2004; Burström et al. 2005a). This seems to have influenced the memories of those who actually experienced the crash, and influenced the folklore surrounding it. Today it almost seems impossible to tell the story of the air torpedo without mentioning Gustafson's kneeling and scared horses. 


\section{RESHAPING MEMORY}

Memories change over time. The interplay between social remembering and object worlds is a growing field of research. Within anthropology the material aspect has often been neglected, while the opposite is true for art and architectural history (Forty \& Küchler 1999). Our archaeological fieldwork in Bäckebo 2004-05 has not just been a survey of existing memories; it has inevitably also conduced to reshape memories and to create new ones. As outsiders our interest in finding out what traces the air torpedo has left no doubt seemed odd or curious to some locals. As it does to some of our archaeological colleagues, we might add. Our exploration has reinforced the impression that the incident in Bäckebo back in 1944 was indeed something special and well worth remembering. The memories of our work are now added to the cultural biographies (cf. Kopytoff 1986) of the impact crater and the rocket parts we have been shown.

Several persons in Bäckebo told us that they had not thought about the air torpedo for many years until the activities that took place in connection with the $50^{\text {th }}$ year anniversary in 1994 . The anniversary made them remember and reflect on what happened back in 1944 . The $60^{\text {th }}$ year anniversary with the exhibition at Kulturmacken in Bäckebo had the same effect, of course, and so did our surveys.

It should be noted that there has been quite a lot of media reports about the air torpedo over the years. Besides a number of shorter articles there was a series of articles published in the daily newspaper Aftonbladet in 1963 (Heed 1963a-d). This series was republished in the weekly magazine Lektyr in 1968 (Heed 1968ab). There was also a special programme on Swedish national television in 1979 (SVT 1979). The reporter Börje Heed, who wrote the article series, talked about the Bäckebo incident in a magazine sent on national television in 1987 (SVT 1987). There he showed a piece of the rocket that was in his possession.

All these reports in the media ought to have made the air torpedo a local topic again during the $1960 \mathrm{~s}$, '70s and ' $80 \mathrm{~s}$. And maybe it did; we cannot know for sure. But since many people claim that the $50^{\text {th }}$ year anniversary in 1994 was the first time they thought about the incident in years, it does not seem likely. It is possible, however, that the anniversary overshadows the memory of earlier media reports.

Today few locals refer to old newspaper articles, and the television programmes seem to be unknown. In spite of this the present folklore is no doubt influenced by past media reports. There are many common features, such as the focus on vital rocket parts and scared horses. Of course these themes are based on what actually once happened, but since then they have been so strongly emphasised by the media that they now seem to occupy all memories and be impossible to pass in silence when speaking about the air torpedo.

The fieldwork conducted together with locals triggered or reinforced a remembering process. For some of the persons we met at the impact crater out in the woods, it was the first time they were there since 1944. Standing there, they surprised themselves by suddenly remembering things they had not thought about 
in decades. The same thing happened when we visited persons in their homes to talk about the rocket parts they possess. Holding the part in their hands, showing it to us, looking at its form and construction, feeling its weight and its surface against their skin, they started to remember things they did not know they still had memories of. The memories told were not restricted to just the incident with the air torpedo itself. The stories often started there but soon included people they knew at the time, what they used to do, places where they met, and much more. The rocket parts are like the famous madeleine biscuit in Marcel Proust's novel In Search of Lost Time (1913-27) - they open the gates of memory.

The air torpedo of Bäckebo reminds us of how soon the most modern becomes the past. And how soon would we not forget, if the material world did not remind us?

\section{ACKNOWLEDGEMENTS}

We want to express our warm thanks to everyone who worked together with us in exploring the traces left by the air torpedo in Bäckebo. Special thanks go to Lena Arén, who has been a great help, and to the Bäckebo Folklore Society for their cooperation.

English revised by Laura Wrang. 


\section{REFERENCES}

Appadurai, A. (Ed). 1986. The Social Life of Things. Commodities in Cultural Perspective. Cambridge University Press. Cambridge.

Arenius, Emma. 2004. Bombjakt i skogen. Barometern, 4-10-2004. Daily paper.

Arenius, Eric. 2004. Bok skildrar hur Bäckebo påverkades av V2-raketen. Östran, 4-10-2004. Daily paper. Arvidsson, A. et al. (Eds). 1990. Människor \& föremål. Etnologer om materiell kultur. Carlssons. Stockholm. Bergaust, E. 1976. Wernher von Braun. National Space Institute. Washington.

Bode, V. \& Kaiser, G. 2002. Raketenspuren. Pennemünde 1936-2000. Ch. Links Verlag. Berlin.

Buchli, V. \& Lucas, B. 2001. The absent present: archaeologies of the contemporary past. In: Archaeologies of the Contemporary Past. Buchli, V. \& Lucas, B. (Eds). Routledge. London \& New York. Pp. 3-18.

Burström, M. 2001. Cultural heritage and antiquarian attitude. Current Swedish Archaeology, Vol. 9, 2001. Pp. 39-44.

- 2004a. Raketbas i ruin väcker tankar om tidens flykt. Svenska Dagbladet, 13-6-2004. Daily paper.

- 2004b. Samtidsarkeologin bryter ny mark. Tvärsnitt, 3:2004. Pp. 50-53.

- 2005. Reliker och rekvisita - vad gör föremål med människor? In: Medeltid på tevetid -en dokusåpas historiedidaktik. Högberg, A. \& Kihlström, H. (Eds). Malmö Museer \& Malmö Kulturmiljö. Pp. 17 30.

Burström, M., Gustafsson, A. \& Karisson, H. 2005a. "När märra knäa". Nedslag i samtidsarkeologin. In: Abstracts, VIII Nordic TAG i Lund 2005. P. 10.

- 2005b. Raketarkeologi - minnen av "Bäckebobomben". Bäckebo sockenkrönika 2004. Pp. 40-43.

-2005c. Rapport angående arkeologisk undersökning med metallsökare. Tillställd Länsstyrelsen i Kalmar län, ref nr 431-5747-04. Unpublished.

Cox, M. 2001. Forensic archaeology in the UK. Questions of socio-intellectual context and socio-political responsibility. In: Archaeologies of the Contemporary Past. Buchli, V. \& Lucas, B. (Eds). Routledge. London \& New York. Pp. 145-157.

Doretti, M. \& Fondebrider, L. 2001 . Science and human rights. Truth, justice, reparation and reconciliation, a long way in Third World countries. In: Archaeologies of the Contemporary Past. Buchli, V. \& Lucas, B. (Eds). Routledge. London \& New York. Pp. 138-144.

Dornberger, W. 1989. Peenemünde. Die Geschichte der V-Waffen. Ullstein. Frankfurt \& Berlin.

Dungan, T. D. 2005. V-2. A Combat History of the First Ballistic Missile. Westholme. Yardley.

Erlandsson, G. 1995. När Bäckebo hamnade på världskartan. Bäckebo sockenkrönika 1994. Pp. 30-33.

Forty, A. \& Küchler, S. (Eds). 1999. The Art of Forgetting. Berg. Oxford \& New York.

Gimbel, J. 1990. German scientists, United States denazification policy, and the paperclip conspiracy. International History Review 12. Pp. 441-85.

Glassie, H. 1999. Material Culture. Indiana University Press. Bloomington \& Indianapolis.

Graves-Brown, P.M. (Ed). 2000. Matter, Materiality and Modern Culture. Routledge. London \& New York.

Håkansson, A. 1987. Framtiden kom till Bäckebo en eftermiddag i juni 1944. Barometern, 2-12-1987. Daily paper.

Hallam, E. \& Hockey, J. 2001. Death, Memory and Material Culture. Berg. Oxford \& New York.

Heed, B. 1963a. Hitlers hemliga skräckvapen (V2) störtade vid svensk bondgård. Aftonbladet, 29-10-1963. Daily paper.

- 1963b. Kom i likbil för att hämta V2-raketen. Aftonbladet, 30-10-1963. Daily paper.

- 1963c. Gömde "hjärnan" på vinden. Aftonbladet, 31-10-1963. Daily paper.

- 1963d. Det var den första raketen i världen! Aftonbladet, 2-11-1963. Daily paper.

- 1968a. Bomben i Bäckebo. Lektyr, 17-2-1968. Weekly magazine.

- 1968b. Världens första överljudsfarkost. Lektyr, 24-2-1968. Weekly magazine.

Hoskins, J. 1998. Biographical Objects. How Things Tell the Stories of People's Lives. Routledge. New York \& London.

Iko, P. 2004. Tysk vedergällning mot Småland! Nationalencyklopedins Internettjünst, www.ne.se. Read in June 2004. 
Jeppsson, T. 2004. När bomben kom till Bäckebo. Barometern, 12-6-2004. Daily paper.

Johansson, R. 1985. Hitlers hemliga vapen. Östra Småland, 3-5-1985. Daily paper.

- 1994. Bäckebobomben hjälpte England stoppa Hitler. Östra Småland, 11-6-1994. Daily paper.

King, B. \& Kutta, T. 1998. Impact. The History of Germany's V-Weapons in World War II. Spellmount Publishers. London.

Kjellson, H. 1944. Rapport angående Bäckebobomben. Saknr: 944-945-946, FIII:15. Försvarsstaben. Stockholm.

Kopytoff, I. 1986. The cultural biography of things: commoditization as process. In: The Social Life of Things. Commodities in Cultural Perspective. Appadurai, A. (Ed). Cambridge University Press. Cambridge. Pp. 64-91.

Longmate, N. 1985. Hitler's Rockets. The Story of the V-2's. Hutchison. London.

Lundgren, K. 1989. Den stora smällen i Bäckebo. Ölandsbladet, 17-10-1989. Daily paper.

Neufeld, M. J. 1995. The Rocket and the Reich. Peenemïnde and the Coming of the Ballistic Missile Era. The Free Press. New York.

Miller, D. (Ed). 1998. Material Cultures. Why Some Things Matter. The University of Chicago Press. Chicago.

Proust, M. 1913-27. A la recherche de temps perdu. Paris.

Rathje, W. \& Murphy, C. 2001. Rubbish! The Archaeology of Garbage. The University of Arizona Press. Tucson.

Schmidt, L. \& von Preuschen, H. (Eds). 2005. On Both Sides of the Wall. Preserving Monuments and Sites of the Cold War Era. Westkreuz-Verlag. Berlin \& Bonn.

Schofield, J. 2005. Combat Archaeology. Material Culture and Modern Conflict. Duckworth. London.

Simpson, C. 1988. Blowback. America's Recruitment of Nazis and Its Effects on the Cold War. Weidenfeld $\&$ Nicholson. New York.

SVT. 1979. Bäckebotorpeden. TV-programme sent on Swedish national television, TV1, 5-2-1979.

- 1987. Café Norrköping. TV-programme sent on Swedish national television, TV2, 2-12-1987.

Vilnersson, O. 1998. Bäckebo lufttorped. Institutionen för humaniora och samhällsvetenskap, Högskolan i Kristianstad. Student paper.

Wahlström, S. 1992. Från Peenemünde till månen. Svensk Flyghistorisk Tidskrift, 6, 1992. Pp. 172-74.

- 1994. Peenemünde med svenska ögon. Flygvapenmuseum. Linköping. 